\title{
Red Rust of Neoregelia Bromeliads Caused by a Parasitic Alga Cephaleuros parasiticus in Florida
}

\begin{abstract}
G. Sanahuja ${ }^{\dagger}$ and P. Lopez, Tropical Research and Education Center, University of Florida, Homestead, 33031; A. J. Palmateer, Tropical Research and Education Center, University of Florida, and Bayer Environmental Science, Homestead, FL, 33031; and A. R. Chase, Chase Agricultural Consulting, Cottonwood, AZ 86326
\end{abstract}

Accepted for publication 5 January 2018.

\begin{abstract}
A newly emerging disease affecting proprietary hybrids of Neoregelia bromeliads was found in nursery production throughout south Florida. Initial symptoms appeared as small, reddish leaf spots with signs of fungal-like growth on the abaxial leaf surface closely resembling a rust. Closer examination of diseased tissue revealed the growth to be an alga with morphological and molecular characteristics of Cephaleuros parasiticus. This genus of plant parasitic thalloid green algae occurs worldwide in tropical and subtropical regions. Isolates of $C$. parasiticus collected from Neoregelia hybrid bromeliads were compared with two common

Cephaleuros spp. (C. parasiticus and C. virescens) causing leaf spots on guava (Psidium guajava) in south Florida. Further, pathogenicity tests were conducted on healthy Neoregelia hybrids using C. parasiticus isolates collected from diseased leaves of bromeliads and guava. Isolates from both sources produced symptoms consistent with those originally described as "red rust" on Neoregelia hybrids. Florida has 165 plant species belonging to 53 families that have been reported as hosts of Cephaleuros spp., but this is the first report on Neoregelia hybrid bromeliads.
\end{abstract}

Cephaleuros species were first reported in Florida by Swingle (1894). A large diversity of hosts has been listed of Cephaleuros species in Florida (up to 165 species), including ornamental plants such as Ligustrum spp., Aglaonema spp., Spathiphyllum spp., Ficus spp., and a wide range of broadleaf plants (Marlatt and Alfieri 1981).

Cephaleuros species are filamentous algae that parasitize numerous species of vascular plants. Most Cephaleuros species are obligate parasites that grow subcuticularly or intercellularly and cause damage to their host plant. Symptoms are often found on leaves but can be found on stems and fruits (Brooks et al. 2015). The severity of diseases caused by Cephaleuros spp. depends on the host plant, the environment, and the species. Cephaleuros species are usually found in tropical and subtropical climates, because warm weather and frequent rains are favorable conditions for their growth and reproduction (Brooks et al. 2015; Nelson 2008).

The macroscopic structure of Cephaleuros species consists of pigmented yellow-orange thalli that are produced on the surface tissue, with filaments bearing sporangiophores and zoosporangia (Thompson and Wujek 1997). The pigmentation of the thalli is owing to accumulation of carotenoids (López-Bautista et al. 2002). Species of Cephaleuros exhibit two different growth habits, and this is one characteristic that can be useful in identifying species. Some are subcuticular species, for which their growth is between the cuticle and epidermis of their hosts. The remainder are intercellular species, for which the alga penetrates the epidermis and grows

${ }^{\dagger}$ Corresponding author: G. Sanahuja; E-mail: g.sanahuja@ufl.edu

Funding was provided by the University of Florida Foundation.

(c) 2018 The American Phytopathological Society among the cells of their hosts (Brooks et al. 2015). Thompson and Wujek (1997) suggested that the features that are most valuable in determining the species of Cephaleuros are the thallus growth habit, the manner of bearing head cells or sporangiate-laterals, and the kind of lesion produced.

This paper presents a new host record for Cephaleuros parasiticus causing red rust on select hybrids of Neoregelia bromeliads. A severe outbreak of red rust appeared in production nurseries and landscapes with a loss up to $90 \%$ in one of the locations in December 2014 in south Florida. Morphological characteristics of the alga causing this new disease on hybrids of Neoregelia bromeliads were compared with descriptions in the monograph by Thompson and Wujek (1997), along with two Cephaleuros species (C. virescens and $C$. parasiticus) occurring on Psidium guajava in south Florida. To confirm its role as a plant pathogen, pathogenicity tests were conducted on Neoregelia hybrids with $C$. parasiticus isolates collected from diseased leaves of bromeliads and guava.

\section{Host and Location of Cephaleuros Species}

Specimens of Cephaleuros species were collected in Homestead, FL, from June 2015 to August 2016 and included two different plant hosts affected with "red rust" on leaves: P. guajava and Neoregelia hybrids. Algal specimens were collected from a variety of $P$. guajava cultivars including 'Patillo', 'Blitch', 'Ruby $\times$ Supreme', 'Webber $\times$ Supreme', 'Asian White', 'Hong Kong Pink', and 'Barbie Pink'.

Samples were randomly collected from diseased bromeliads in a local nursery and from a guava orchard located at the University of Florida (UF) Tropical Research and Education Center (TREC) in Homestead, FL (latitude, $25^{\circ} 30^{\prime} 40.809^{\prime \prime} \mathrm{N}$; longitude, $80^{\circ} 30^{\prime} 3.983^{\prime \prime} \mathrm{W}$ ).

Specimens of $C$. parasiticus collected from Neoregelia bromeliad hybrids and $C$. parasiticus and $C$. virescens collected from $P$. guajava 'Webber $\times$ Supreme' were deposited in the Smithsonian 
Institution, Department of Botany, Washington DC (accession numbers not assigned by this institute).

\section{Morphological Characteristics}

Morphological characteristics of Cephaleuros thalli were observed using a Keyence microscope (model VHX-900F, Keyence Corporation of America, Itasca, IL) and transverse leaf sections were observed using a Laborlux microscope (Leitz, Wetzlar, Germany), and images were taken with a Pixelink camera (model PL-AA62, Pixelink, Ottawa, Canada). Several sections were made by hand using a sterile blade and were placed in a drop of Shear's fluid as described in Suto et al. (2014) on a glass slide with a cover slip sealed to observe under the microscope. The leaf cuticle was carefully removed from some of the sections as described in Preece (1962), modifying the antibacterial reagent. Plant preservative mixture (Caisson Laboratories, Smithfield, UT) was used to prevent bacterial contamination, and after 2 and 5 days, cuticles floated free in the solution. Sporangiophores and zoosporangia dimensions were measured $(n=50)$.

\section{Pathogenicity Tests}

Pathogenicity tests were performed on an asymptomatic healthyappearing Neoregelia hybrid as well as a commercial variety, Neoregelia carolinae 'Tricolor perfecta'. The trial was run from March to September 2016 at UF TREC in Homestead, FL. Bromeliads were inoculated with zoosporangia from three $C$. parasiticus isolates (strains NEO 141075, NEO 4 N 41516, and NEO B1 111715) collected from a Neoregelia hybrid and strain GUAAW 1.7, collected from $P$. guajava. $C$. virescens from $P$. guajava was not included in the pathogenicity test owing to the lack of an inoculum source. Inocula were prepared from small pieces of symptomatic leaf spot tissue processed in a blender (Magic Bullet Blender, model MB 1001) prior to filtering through sterile cheesecloth (gauze sponges, McKesson, Richmond, VA). A zoosporangia suspension ranging from $1 \times 10^{2}$ to $1 \times 10^{4}$ zoosporangia/ $\mathrm{ml}$ was sprayed over the foliage until runoff with a handheld air pump sprayer. Two plants were inoculated with each strain, and two noninoculated control plants were included. Noninoculated controls were sprayed with sterile deionized water. The pathogenicity experiment was repeated.

Plants were located in a humidity chamber under $73 \%$ shade (outdoor shadehouse) and arranged in a randomized complete block design. They were monitored for symptom development weekly. Temperature and relative humidity $(\mathrm{RH})$ were recorded with a HOBO data logger (model U12-012, Onset, Bourne, MA) throughout the duration of the trials.

\section{C. parasiticus on Neoregelia Hybrid Leaves}

Small reddish elliptical lesions approximately 0.1 to $10 \mathrm{~cm}$ in length and 0.1 to $4 \mathrm{~cm}$ wide resembling "red rust" initially developed on the adaxial leaf surface and progressed through to the abaxial surface. The red spots appearing on the adaxial leaf surface eventually turned brown, forming characteristic red halos (Fig. 1A). The first red spot symptoms on the adaxial leaf surface developed 8 weeks after inoculation, and at 10 weeks spots turned brown with red halos (Fig. 1A). Symptoms caused by C. parasiticus (from the two isolates of different hosts) appeared at an average temperature of $26^{\circ} \mathrm{C}$ and $80 \% \mathrm{RH}$ on both Neoregelia species. On the abaxial leaf surface, brown spots became covered with orange tufts of sporangiophores releasing zoosporangia (Fig. 1B). Over time, these
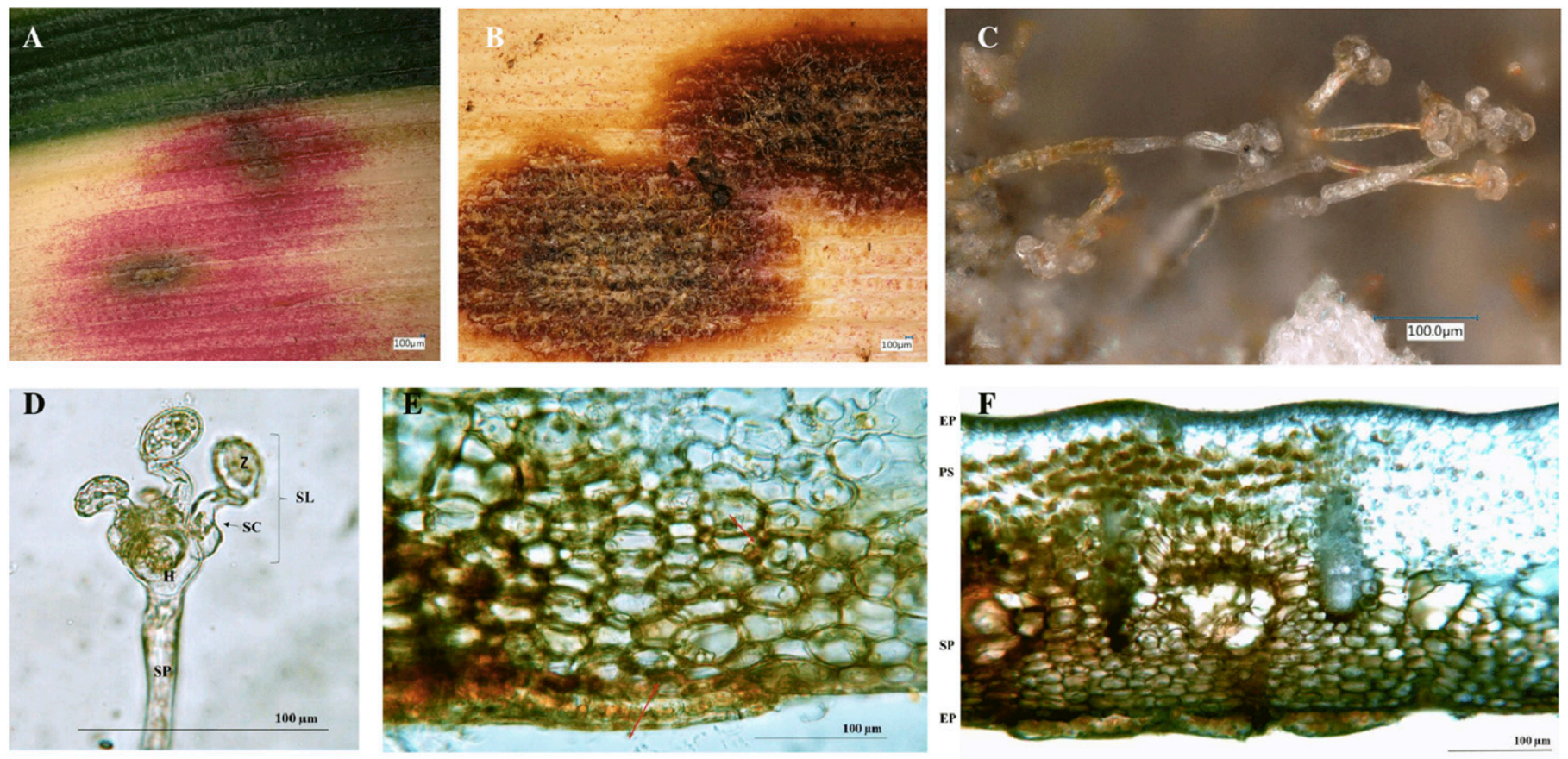

FIGURE 1

Leaf lesions caused by Cephaleuros parasiticus on Neoregelia hybrids. A, Brown lesions surrounded by red halos on the adaxial leaf surface. B, Brown lesions covered with tufts of sporangiophores on the abaxial leaf surface. C, Sporangiophores with zoosporangia on the abaxial leaf surface. D, Sporangiophore with zoosporangia. $\mathrm{H}$ = head cell; SC = suffultory cell; SL = sporangiate-lateral; SP = sporangiophore; and Z = zoosporangia. $\mathbf{E}$, Transverse section of leaf lesion showing C. parasiticus filaments growing among the cells of their Neoregelia hybrid host (intercellular). Red arrows show the C. parasiticus filaments. F, Transverse section of leaf lesion showing necrosis of epidermal (EP), palisade (PS), and spongy mesophyll cells (SP). Scale bars represent $100 \mu \mathrm{m}$. 
tufts were observed on the adaxial leaf surface. Evidence of sporangiophores releasing zoosporangia on the abaxial leaf surface appeared at 12 weeks.

Sporangiophores were cylindrical, erect, 150 to $375 \pm 21.74 \mu \mathrm{m}$ long and 9.4 to $15 \pm 0.84 \mu \mathrm{m}$ wide, with 3 to 7 cells $(n=50)$. Head cells were borne terminally on sporangiophores and produced 3 to 6 sporangiate laterals. Zoosporangia and their suffultory cells were flexed and bent (Fig. 1C and D). Zoosporangia were elliptical, 15 to $25 \pm 1.2 \mu \mathrm{m}$ long and 12.5 to $20 \pm 1.03 \mu \mathrm{m}$ wide, and appeared white to orange in color $(n=50)$ (Fig. 1D).

Thalli grew subepidermally, developed vertically beneath epidermal cells, and emerged intercellularly through the epidermis,
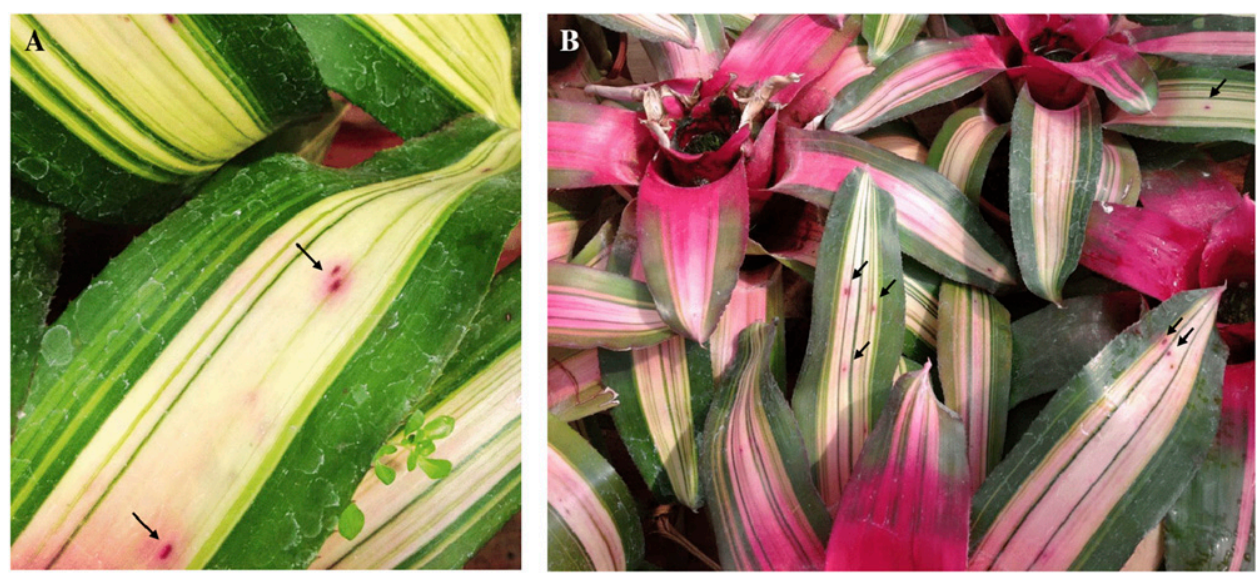

FIGURE 2

Red leaf spot symptoms caused by Cephaleuros parasiticus of Neoregelia species. A, Symptoms on Neoregelia hybrids inoculated with C. parasiticus isolated from Neoregelia hybrids. Arrows show the red leaf spot caused by C. parasiticus. B, Pathogenicity tests on Neoregelia carolinae cv. 'Tricolor perfecta'. Arrows show the symptoms of $C$. parasiticus isolated from Psidium guajava causing red leaf spot.
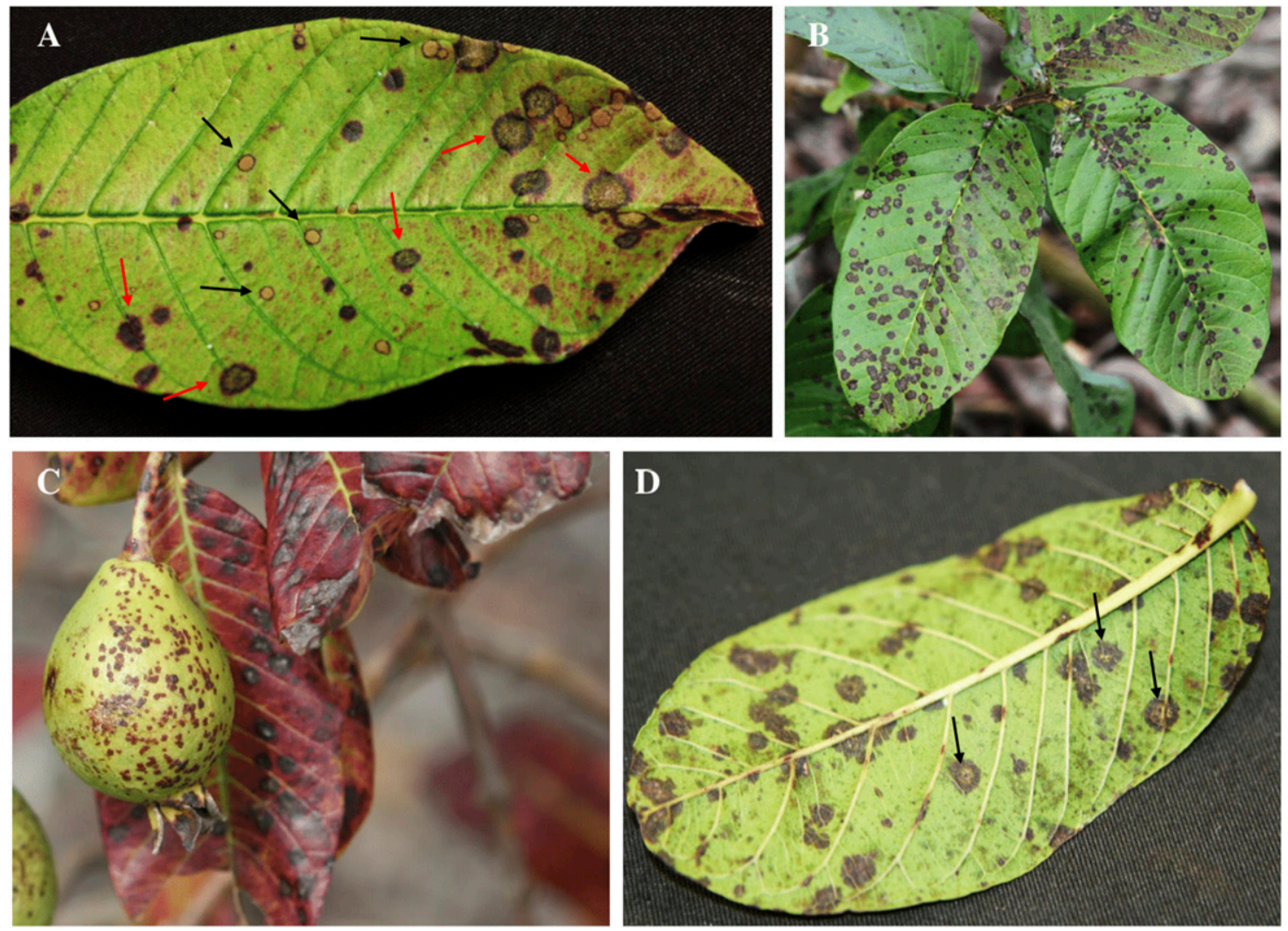

\section{FIGURE 3}

Lesions caused by Cephaleuros spp. on Psidium guajava. A, Cephaleuros spp. on Psidium guajava leaves. Black arrows show Cephaleuros virescens causing orange spots, and red arrows show Cephaleuros parasiticus causing dark-reddish brown spots. Photo taken from the adaxial leaf surface. B, Algae leaf spot on $P$. guajava caused by C. parasiticus. C, Algae spot on P. guajava caused by C. parasiticus on leaves and on fruits. D, Algae leaf spot on $P$. guajava caused by C. parasiticus on the abaxial surface. Arrows show the yellow-orange algae thalli on the abaxial leaf surface. 
spongy mesophyll cells, and palisade cells (Fig. 1E and 1F). Necrosis was observed in epidermal, palisade, and spongy mesophyll cells, appearing brown to dark brown (Fig. 1F).

Koch's postulates and the host range test demonstrated the pathogenicity of the causal agent of the disease on Neoregelia hybrids. Additionally, N. carolinae cv. 'Tricolor perfecta' was also susceptible but to a lesser degree than Neoregelia hybrids (Fig. 2A and B). C. parasiticus from P. guajava also infected both Neoregelia species, and leaf spots symptoms closely resembled the original disease samples 8 weeks after the first inoculation (Fig. 2B). C. parasiticus was reisolated from symptomatic leaf tissue and was confirmed based on molecular and morphological characteristics. No symptoms developed on any noninoculated control plant.

C. parasiticus on Neoregelia hybrids was described from red spots turning brown with time, eventually producing orange tufts of sporangiophores producing zoosporangia with head cells borne terminally on the abaxial leaf surface. Thalli of $C$. parasiticus on Neoregelia hybrids grow subepidermally, develop vertically beneath epidermal cells, and grow into intercellular space of cells, showing necrosis of epidermal, palisade, and spongy mesophyll cells. The same characteristics were described for $C$. parasiticus on P. guajava (Sunpapao et al. 2016), C. parasiticus on Syzygium aromaticum (Suto et al. 2014), and C. parasiticus on Magnolia grandiflora (Chapman and Henk 1985).

\section{Cephaleuros Species on $\boldsymbol{P}$. guajava Leaves}

Two species of the genus Cephaleuros have been observed causing leaf and fruit spots on P. guajava in south Florida. C. virescens causes orange leaf spots that are generally much less severe than the "red rust" caused by C. parasiticus (Fig. 3A). C. parasiticus symptoms are attributed to dark, reddish brown spots occurring on the fruit and on both sides of the leaf surface of $P$. guajava (Fig. 3). Figure 3B and $\mathrm{C}$ shows the high incidence and severity of $C$. parasiticus on $P$. guajava leaves and fruit in south Florida. Pigmented yellow-orange thalli of $C$. parasiticus occur on the abaxial surface (Fig. 3D), whereas pigmented orange thalli occur on the adaxial surface for $C$. virescens (Fig. 3A).

Leaf and fruit spots caused by $C$. parasiticus on $P$. guajava were characteristically circular, dark red in early symptoms, and dark reddish-brown at maturity, approximately 0.1 to $6 \mathrm{~cm}$ in diameter (Fig. 3B and C). Yellow-orange tufts of sporangiophores with zoosporangia were produced in clusters and were observed solely on the abaxial leaf surface (Fig. 4A, B, and C). Sporangiophores were cylindrical, erect, 100 to $128 \pm 3.53 \mu \mathrm{m}$ in length and 10 to 15 $\pm 0.69 \mu \mathrm{m}$ wide, with 1 to 4 cells $(n=50)$. Head cells were borne terminally on the sporangiophores and produced 1 to 6 sporangiate laterals, zoosporangia, and their suffultory cells. Zoosporangia were elliptical, 15 to $25 \pm 0.67 \mu \mathrm{m}$ in length and 15 to $25 \pm 0.96 \mu \mathrm{m}$ wide, white to orange $(n=50)$ (Fig. 4C). Sporangiophore initials of $C$. parasiticus were observed on the abaxial leaf surface of $P$. guajava (Fig. 4B). The thalli grew subepidermally and caused necrosis of epidermal, palisade, and spongy mesophyll cells (Fig. 4D and E).

Leaf spots caused by $C$. virescens on $P$. guajava were characteristically small orange circular leaf spots approximately 0.1 to $0.4 \mathrm{~cm}$ in diameter (Fig. 3A). Orange tufts of sporangiophores with zoosporangia developed solely on the adaxial leaf surface (Fig. 5A and B). Sporangiophores were cylindrical, erect, 225 to $450 \pm 21.5 \mu \mathrm{m}$ long and 10 to $20 \pm 0.9 \mu \mathrm{m}$ wide, with 1 to 6 cells $(n=50)$. Head cells were borne terminally on the sporangiophores and produced 2 to 7 sporangiate laterals, zoosporangia, and their suffultory cells,
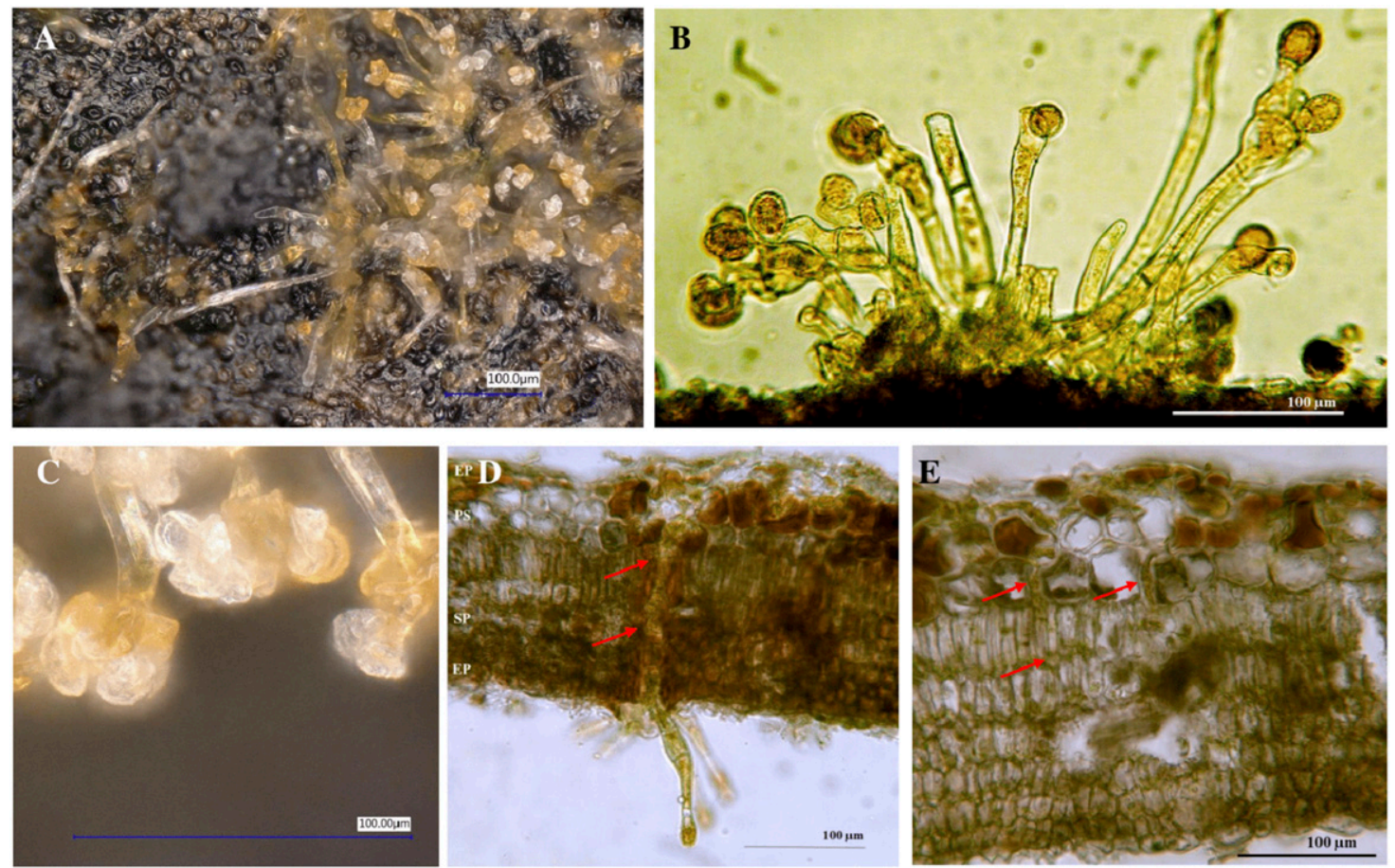

\section{FIGURE 4}

Leaf lesions caused by Cephaleuros parasiticus on Psidium guajava. A, Sporangiophores with zoosporangia on the abaxial leaf surface. B, Sporangiophore initials of $C$. parasiticus on the abaxial leaf surface of $P$. guajava host. C, Sporangiophores with zoosporangia on the abaxial leaf surface. D, Transverse section of leaf lesion showing with red arrows C. parasiticus filaments growing among the cells of their P. guajava host (intercellular). Note necrosis of epidermal (EP), palisade (PS), and spongy mesophyll cells (SP). E, Transverse section of leaf lesion showing with red arrows C. parasiticus filaments growing among the cells of their P. guajava host (intercellular). Scale bars represent $100 \mu \mathrm{m}$. 


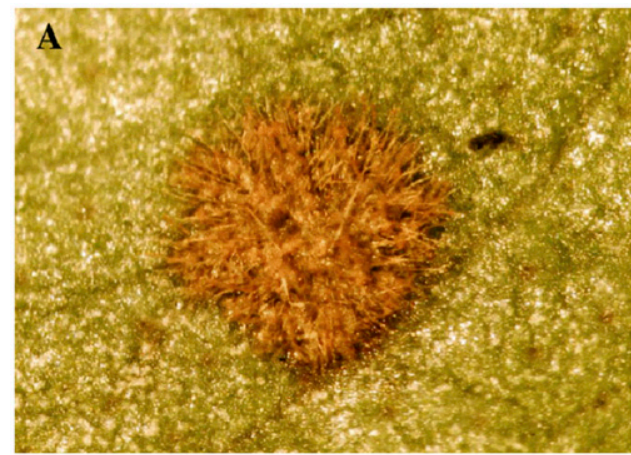

C

B

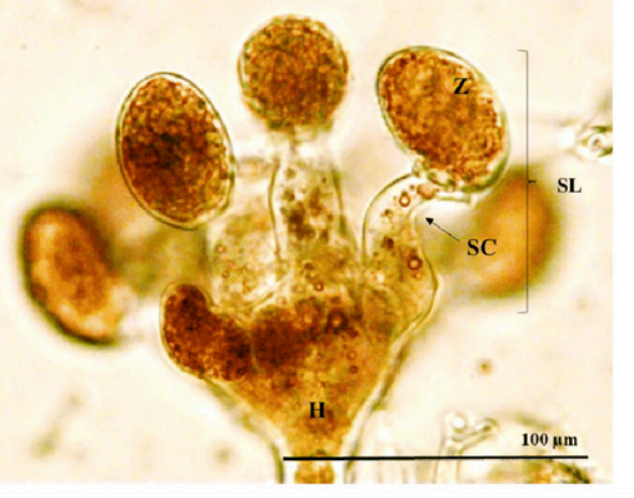

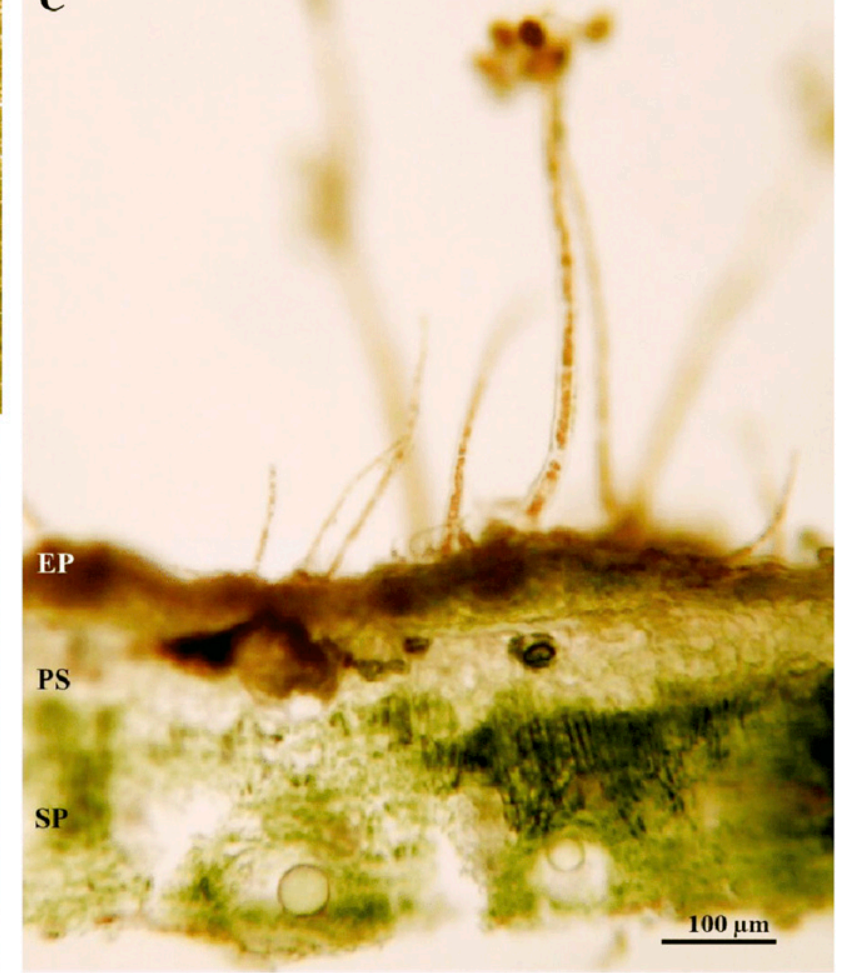

FIGURE 5

Leaf lesions caused by Cephaleuros virescens on Psidium guajava. A, Orange alga thalli of $C$. virescens on adaxial leaf surface. B, Sporangiate lateral of $C$. virescens. $\mathrm{H}=$ head cell; $\mathrm{SC}=$ suffultory cell; $\mathrm{SL}=$ sporangiate lateral; and $\mathrm{Z}=$ zoosporangia. $\mathbf{C}$, Transverse section of leaf lesion showing $C$. virescens on the adaxial leaf surface and necrosis of epidermal (EP) and palisade cells (PS) of $P$. guajava. Scale bars represent $100 \mu \mathrm{m}$.

which were flexed (Fig. 5B). Zoosporangia were globular to elliptical, 16 to $30 \pm 1.1 \mu \mathrm{m}$ long and 15.6 to $25 \pm 0.7 \mu \mathrm{m}$ wide, appearing white to orange in color $(n=50)$. Thalli of $C$. virescens on $P$. guajava grew subcuticularly on the adaxial and not on the abaxial leaf surface and caused necrosis of epidermal and palisade cells (Fig. 5C).

\section{Molecular Characterization of Cephaleuros Species}

Three representative isolates of $C$. parasiticus were assessed at DNA level from different various locations from Neoregelia hybrids plants (strain NEO 141075, strain NEO 4 N 41516, and strain NEO B1 111715), in addition to one isolate of C. parasiticus (strain GUA-AW 1.7 cultivar 'Asian White') and one isolate of $C$. virescens (strain GUA-WS 4.14 cultivar 'Webber $\times$ Supreme').

Total DNA from isolates of all Cephaleuros species collected was extracted from symptomatic leaf spots. Leaves were rinsed with sterilized water to remove potential contamination from other organisms, and afterward Cephaleuros cells were carefully scraped by blade into a $1.5-\mathrm{ml}$ tube with sterile distilled water. Cells were disrupted with a Tissuemiser (Fisher Scientific, Waltham, MA), and the DNA was extracted as described with the DNeasy Plant Mini kit (Qiagen, Valencia, CA). DNA was stored at $4^{\circ} \mathrm{C}$ prior to use. The integrity of DNA was checked by electrophoresis $1 \%$ agarose gels previously premixed with GelRed Nuclei Acid Stain (Phenix Research Products, Candler, NC).

PCR was performed for the $18 \mathrm{~S}$ ribosomal RNA (rRNA) gene. Primers used for $18 \mathrm{~S}$ rRNA were PCRA $\left(5^{\prime}\right.$-AACCTGGTTGAT CCTGCCAGT-3') (Medlin et al. 1988), 18H (5'-GCCCTTCCG TCAATTCCTTTAAGTTTCAGC-3') (Hamby and Zimmer 1988), and/or RP8 (5'-ACCTGGTTGATCCTGCCAGTAG-3') and RP9
(5'-ACCTTGTTACGACTTCTCCTTCCTC-3') (Zhang et al. 2008). RP8 and RP9 primers were used to detect and eliminate the contaminating presence of unicellular Chlorella-like green algae (Ma et al. 2013; Zhang et al. 2008).

Template DNA $(2 \mu \mathrm{l}, 50 \mathrm{ng} / \mu \mathrm{l})$ was amplified in a total reaction volume of $25 \mu$ l containing $2.5 \mu \mathrm{l}$ of $10 \times$ reaction buffer, $1.25 \mu \mathrm{l}$ of $\mathrm{MgCl}_{2}(50 \mathrm{mM}), 0.5 \mu \mathrm{l}$ of deoxynucleotide mixture (containing dATPs, dTTP, dCTP, and dGTP, $10 \mathrm{mM}$ ), $1.25 \mu \mathrm{l}$ of each primer $(10 \mu \mathrm{M}), 0.1 \mu \mathrm{l}$ of Taq (1U, New England Biolabs, Ipswich, MA), and sterile water. The PCR protocol for $18 \mathrm{~S}$ rRNA for primers PCRA and $18 \mathrm{H}$ consisted of an initial denaturing phase of $3 \mathrm{~min}$ at $95^{\circ} \mathrm{C}$, followed by 30 cycles of $95^{\circ} \mathrm{C}$ for $1 \mathrm{~min}, 56^{\circ} \mathrm{C}$ for $1 \mathrm{~min}$, and $72^{\circ} \mathrm{C}$ for $1.5 \mathrm{~min}$, with a final extension of $7 \mathrm{~min}$ at $72^{\circ} \mathrm{C}$. The PCR protocol for RP8 and RP9 primers consisted of an initial denaturing phase of $5 \mathrm{~min}$ at $94^{\circ} \mathrm{C}$, followed by 30 cycles of $94^{\circ} \mathrm{C}$ for $30 \mathrm{~s}$, $58^{\circ} \mathrm{C}$ for $30 \mathrm{~s}$, and $72^{\circ} \mathrm{C}$ for $2 \mathrm{~min}$, with a final extension of $10 \mathrm{~min}$ at $72^{\circ} \mathrm{C}$ (Ma et al. 2013). PCR fragments for $18 \mathrm{~S}$ rRNA for Neoregelia hybrids were cloned into PCR 2.1-TOPO vector using the TOPO TA cloning kit (Invitrogen, Carlsbad, CA) according to the manufacturer's instructions. Prior to ligation into the cloning vector, PCR products were cleaned using QIAquick Gel Extraction Kit (Qiagen) following the manufacturer's recommendations. A 3' A-overhang was added to the PCR product after purification to facilitate the ligation into the cloning vector by mixing, with a final volume of $20 \mu \mathrm{l}$, the purified PCR product with $2 \mu \mathrm{l}$ of $10 \times$ reaction buffer, $5 \mu$ l of dATP $(10 \mathrm{mM})$, and $0.1 \mu \mathrm{l}$ of Taq (1U, New England Biolabs). The reaction was placed in a thermocycler at $72^{\circ} \mathrm{C}$ for 20 min, and the product was immediately ligated into the cloning vector. Escherichia coli DH5 $\alpha$ competent cells (Invitrogen) were 
used for transformation with the recombinant plasmid. E. coli colonies were grown overnight at $37^{\circ} \mathrm{C}$ on Luria-Bertani (Becton, Dickinson, and Co., Franklin Lakes, NJ) medium plates containing ampicillin $(100 \mu \mathrm{g} / \mathrm{ml})$ and 5-bromo-4-chloro-3-indolyl- $\beta$-Dgalactopyranoside $(20 \mu \mathrm{g} / \mathrm{ml}, \mathrm{X}-\mathrm{Gal}$, Thermo Fisher Scientific, Waltham, MA). Colonies were screened by PCR, and plasmid DNA from the positive colonies was purified using the PureYield Miniprep System (Promega, Madison, WI). Samples were sequenced using the standard cycle sequencing technology (dideoxy chain termination/ cycle sequencing) on ABI 3730XL sequencing machines (Eurofins MWG Genomics, Louisville, KY). Primers used for sequencing were PCRA, 18H, and GRC (Hamby and Zimmer 1988; Rindi et al. 2009). Sequences were deposited into the National Center for Biotechnology Information (NCBI) GenBank (https://www.ncbi.nlm.nih. gov/genbank/). The accession numbers at GenBank for the three isolates of $C$. parasiticus of Neoregelia hybrids plants (strain NEO 141075, strain NEO 4 N 41516, and strain NEO B1 111715) were KY305499, KY305498, and KY305497, respectively. The accession number for Cephaleuros species from P. guajava were KY305496 for $C$. parasiticus strain GUA-AW 1.7 cultivar 'Asian White' and KY305495 for $C$. virescens strain GUA-WS 4.14 cultivar 'Webber $\times$ Supreme'.

The sequences obtained had $99 \%$ identity (100\% query; E-value 0.0 ) with either $C$. parasiticus (accession number KM020146) and C. virescens (accession number KM020145). Phylogenetic analysis based on $18 \mathrm{~S}$ rRNA sequences was performed using the maximum likelihood method based on the Tamura-Nei model (Tamura and Nei 1993). Evolutionary analyses were conducted in MEGA7 (Kumar et al. 2016). The strains of $C$. parasiticus from Neoregelia hybrids and from $P$. guajava formed a clade with $90 \%$ support between them (1,000 replicates) (Fig. 6).

\section{Conclusion and Management Implications}

C. virescens appears to be the most common widespread species of the genus (Brooks 2004; Brooks et al. 2015; Holcomb 1986; Thompson and Wujek 1997). In the Homestead area of south Florida, it has recently been observed causing leaf spot on adaxial leaf surface on Vitex negundo, Pachira aquatica, Litchi chinensis, Mangifera indica, and Dimocarpus longan (UF/IFAS Florida Extension Plant Diagnostic Clinic, Homestead, FL, reports). This is the first report in south Florida of the appearance of both Cephaleuros species, $C$. virescens and $C$. parasiticus, in the same leaf host on P. guajava, L. chinensis, and $M$. indica (UF/IFAS Florida Extension Plant Diagnostic Clinic reports; in this study).

Based on morphology, Cephaleuros isolates found in this study were identified to genus and species levels. Sequences of the Cephaleuros isolates found in this study cluster in the genus of Cephaleuros, and the strains of $C$. parasiticus from Neoregelia hybrids cluster with the strain of $C$. parasiticus from $P$. guajava. Rindi et al. (2009) also showed that a high number of strains from Cephaleuros sequences found in different places worldwide cluster with Cephaleuros genera with high support sequences in a clade with either the 18S rRNA or the rubisco (ribulose-1,5-bisphosphate carboxylase/oxygenase, $r b c l$ ) genes. More DNA sequences need to be analyzed in that genus, but one of the challenges is that DNA sequences from that order have only recently become available (Rindi et al. 2009), and DNA extraction can be easily contaminated with unicellular algae from the Trebouxiophyceae class that are found in terrestrial environments where Cephaleuros spp. grow.

$C$. parasiticus infections on $P$. guajava (guava) have been misidentified as guava rust caused by Puccinia psidii (Nelson 2008). Similarly, red leaf spot on Camellia sinensis is caused by C. parasiticus but is often misdiagnosed as "red rust" (Brooks et al. 2015). Yellow-orange tufts of sporangiophores with zoosporangia observed solely on the abaxial leaf surface of $C$. parasiticus on $P$. guajava sometimes resemble symptoms of guava rust. $P$. psidii produces pale yellow uredia, with pustules on the foliage, and it was first described on P. guajava in Brazil (Burnett and Schubert 1985). Subsequently, it has been recorded on several genera of native Myrtaceae in Central and South America. In Florida, P. psidii was first found in 1977 (Rayachhetry et al. 1997), where it severely damaged native Myrtaceae, and also the introduced Australian Melaleuca quinquenervia (Huq et al. 2010). In 2006, three different host of $P$. psidii rust were identified in Homestead (south Florida),

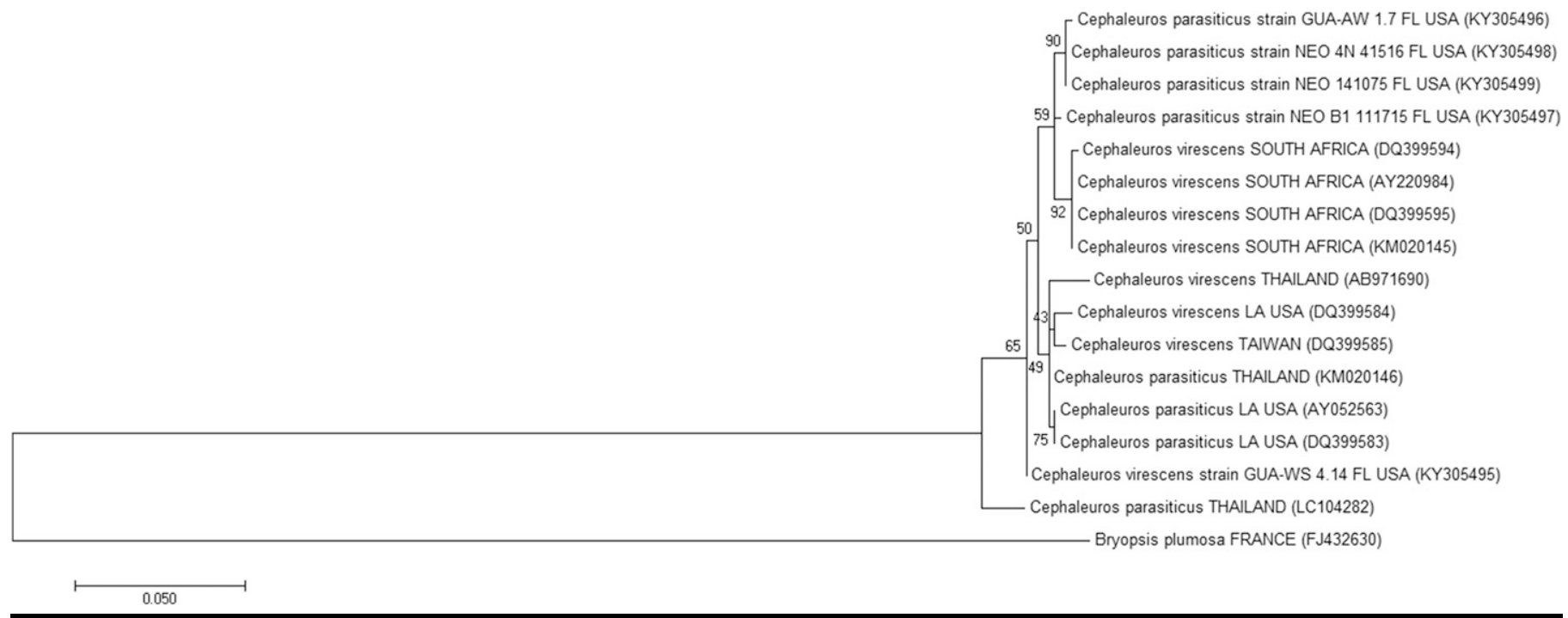

FIGURE 6

Phylogenetic tree from maximum likelihood analysis using 18S rRNA sequences of Cephaleuros strains from this study and other Cephaleuros species. Cephaleuros parasiticus from Neoregelia hybrids (strain NEO 141075, strain NEO 4 N 41516, and strain NEO B1 111715) cluster with C. parasiticus from Psidium guajava (strain GUA-AW 1.7). The tree was rooted using an outgroup sequence of Bryopsis plumosa. The bootstrap values are shown on the branches, and the GenBank accession numbers are shown on parenthesis. 
Myrcianthes fragrans, Syzygium jambos, and Pimenta dioica (allspice) (UF/IFAS Florida Extension Plant Diagnostic Clinic, Homestead, FL, reports). However, to date, rust caused by $P$. psidii on guava in Florida has never been observed. Although rust diseases on many plants are often managed through use of fungicides, control of algal leaf spot is not successful with algaecides (A. R. Chase, personal communication). Even use of copper-based fungicides is not effective in preventing algal leaf spot. The relatively close relationship of the host crop with the parasitic algal pathogen makes chemical control unlikely without damage to the host crop. Therefore, cultural controls are the sole means of addressing algal leaf spot on most plants.

Major predisposing factors to severe algae infection are considered to include plant stress caused by insufficient water or nutrients, poor soil conditions, mechanical harvesting or overharvesting, wounding, and disease (Brooks et al. 2015). Therefore, cultural practices on reducing plant stress and improving plant vigor are the best strategy to address the disease (Ramya et al. 2013; Suto and Ohtani 2013). These practices include proper irrigation and plant nutrition, thinning to improve aeration in the canopy, proper harvesting techniques, and control of pests and diseases (Brooks et al. 2015; Ramya et al. 2013; Suto and Ohtani 2013).

\section{Acknowledgments}

The authors thank Daniel Carrillo and Rita E. Duncan at the University of Florida-IFAS, Tropical Research and Education Center, for supporting the work with the Keyence microscope.

\section{Literature Cited}

Brooks, F., Rindi, F., Suto, Y., Ohtani, S., and Green, M. 2015. The Trentepohliales (Ulophyceae, Chlorophyta): An unusual algal order and its novel plant pathogen, Cephaleuros. Plant Dis. 99:740-753.

Brooks, F. E. 2004. Plant-parasitic algae (Chlorophyta: Trentepohliales) in American Samoa. Pac. Sci. 58:419-428.

Burnett, H. C., and Schubert, T. S. 1985. Puccinia psidii on allspice and related plants. Plant Pathology Circular No. 271. Division of Plant Industry, Florida Department of Agriculture and Consumer Services, Tallahassee, FL.

Chapman, R. L., and Henk, M. C. 1985. Observations on the habit, morphology and ultrastructure of Cephaleuros parasiticus (Chlorophyta) and a comparison with $C$. virescens. J. Phycol. 21:513-522.

Hamby, R. K., and Zimmer, E. A. 1988. Ribosomal RNA sequences for inferring phylogeny within the grass family (Poaceae). Plant Syst. Evol. 160:29-37.

Holcomb, G. E. 1986. Hosts of the parasitic alga Cephaleuros virescens in Louisiana and new host records for the continental United States. Plant Dis. 70:1080-1083
Huq, M., Ali, M., and Islan, M. S. 2010. Efficacy of muriate of potash and foliar spray with fungicides to control red rust disease (Cephaleuros parasiticus) of tea. Bangladesh J. Agric. Res. 35:273-277.

Kumar, S., Stecher, G., and Tamura, K. 2016. MEGA7: Molecular Evolutionary Genetics Analysis version 7.0 for bigger datasets. Mol. Biol. Evol. 33:1870-1874.

López-Bautista, J. M., Waters, D. A., and Chapman, R. L. 2002. The Trentepohliales revisited. Constancea 83. http://ucjeps.berkeley.edu/constancea/83/lopez_etal/ trentepohliales.html.

Ma, S., Huss, V. A. R., Tan, D., Sun, X., Chen, J., Xie, Y., and Zhang, J. 2013. A novel species in the genus Heveochlorella (Trebouxiophyceae, Chlorophyta) witnesses the evolution from an epiphytic into an endophytic lifestyle in treedwelling green algae. Eur. J. Phycol. 48:200-209.

Marlatt, R. B., and Alfieri, S. A., Jr. 1981. Hosts of a parasitic alga, Cephaleuros Kunze, in Florida. Plant Dis. 65:520-522.

Medlin, L., Elwood, H. J., Stickel, S., and Sogin, M. L. 1988. The characterization of enzymatically amplified eukaryotic 16s-like rRNA-coding regions. Gene 71:491-499.

Nelson, S. C. 2008. Cephaleuros species, the plant-parasitic green algae. Plant Dis. 43:1-6.

Preece, T. F. 1962. Removal of apple leaf cuticle by pectinase to reveal the mycelium of Venturia inaequalis (Cooke) Wint. Nature 193:902-903.

Ramya, M., Ponmurugan, P., and Saravanan, D. 2013. Management of Cephaleuros parasiticus Karst (Trentepohliales: Trentepohliaceae), an algal pathogen of tea plant, Camellia sinsensis (L) (O. Kuntze). Crop Prot. 44: 66-74.

Rayachhetry, M. B., Elliott, M. L., and Van, T. K. 1997. Natural epiphytotic of the rust Puccinia psidii on Melaleuca quinquenervia in Florida. Plant Dis. 81: 831.

Rindi, F., Lam, D. W., and López-Bautista, J. M. 2009. Phylogenetic relationships and species circumscription in Trentepohlia and Printzina (Trentepohliales, Chlorophyta). Mol. Phylogenet. Evol. 52:329-339.

Sunpapao, A., Thithuan, N., Bunjongsiri, P., and Arikit, S. 2016. Cephaleuros parasiticus, associated with algal spot disease on Psidium guajava in Thailand. Australas. Plant Dis. Notes 11:12.

Suto, Y., Ganesan, E. K., and West, J. A. 2014. Comparative observations on Cephaleuros parasiticus and C. virescens (Trentepohliaceae, Chlorophyta) from India. Algae 29:121-126.

Suto, Y., and Ohtani, S. 2013. Seasonal development of five Cephaleuros species (Trentepohliaceae, Chlorophyta) on the leaves of woody plants and the behaviors of their gametes and zoospores. Phycol. Res. 61:105-115.

Swingle, W. T. 1894. Cephaleuros mycoidea and Phyllosiphon, two species of parasitic algae new to North America. Proc. Am. Assoc. Adv. Sci. 42:260 (Abstr.).

Tamura, K., and Nei, M. 1993. Estimation of the number of nucleotide substitutions in the control region of mitochondrial DNA in humans and chimpanzees. Mol. Biol. Evol. 10:512-526.

Thompson, R. H., and Wujek, D. 1997. Pages 1-149 in: Trentepohliales: Cephaleuros, Phycopeltis, and Stomatochroon. Morphology, Taxonomy, and Ecology. Science Publishers, India.

Zhang, J. H., Huss, V. A. R., Sun, X., Chang, K., and Pang, D. 2008. Morphology and phylogenetic position of a trebouxiophycean green alga (Chlorophyta) growing on the rubber tree, Hevea brasiliensis, with the description of a new genus and species. Eur. J. Phycol. 43:185-193. 